\title{
58. BIOSTRATIGRAPHY OF CALCAREOUS NANNOFOSSILS: LEG 34, DEEP SEA DRILLING PROJECT
}

\author{
Gretchen Blechschmidt, Department of Oceanography, University of Washington, Seattle, Washington
}

\begin{abstract}
Forty-four cores were recovered from three drill sites during Leg 34 of the Deep Sea Drilling Project in the southeastern Pacific. Calcareous nannofossils ranging in age from late Eocene to Quaternary were found in 24 of these cores. The Neogene is well represented at Site 319 and partially represented at Site 320. For the most part, calcareous nannofossils are absent or poorly preserved in the PlioPleistocene interval at all three sites. The Miocene interval was continuously cored at Site 319, and calcareous nannofossils are fairly well preserved in this interval. Site 320 was intermittently cored in three holes, penetrating primarily lower Miocene sediments. The Neogene interval at Site 321 is barren of calcareous nannofossils, except for a fairly diverse, well-preserved upper Oligocene/lower Miocene flora at a depth of about 58 meters. The only Paleogene sediments found on Leg 34 were recovered at Site 321, where a nearly complete Oligocene section extending into the upper Eocene was cored.
\end{abstract}

\section{INTRODUCTION}

Three sites were drilled in the southeastern Pacific during Leg 34 (Figure 1). These are: Site 319, located in the Bauer Deep between the Galapagos Rise and the East Pacific Rise; Site 320, located about 200 miles off the western coast of Peru; and Site 321, also located off the western coast of Peru. Calcareous nannofossils were found at all three sites which presently lie below the carbonate compensation depth. (CCD). The presence of carbonates in the sediments probably reflects a combination of factors including subsidence, which has brought these sites below the CCD, and large-scale fluctuations of the CCD through geologic time (van Andel et al., in preparation). These factors and their influence on the geologic history of the area are discussed in detail by Quilty et al. (this volume). The purpose of this study is threefold: (1) to determine the biostratigraphic relationships of the calcareous nannofossils recovered during Leg 34; (2) to record and present data on the preservation of the nannofossils; and (3) to provide data to aid in the reconstruction of the geologic history of the area.

\section{BIOSTRATIGRAPHY}

Cenozoic calcareous nannoplankton zonations have been established by a number of investigators, primarily based on land or epicontinental sections (Bramlette and Sullivan, 1961; Bramlette and Wilcoxon, 1967; Hay et al., 1967; Gartner, 1969; Martini, 1971; Edwards, 1971; and Bukry, 1973). With the increase in data available from the deep sea, it has become apparent that landbased zonation schemes are not always applicable in the deep sea. This probably is the result of several factors, the most obvious of which is selective dissolution of solution-susceptible taxa in deep water sections and the

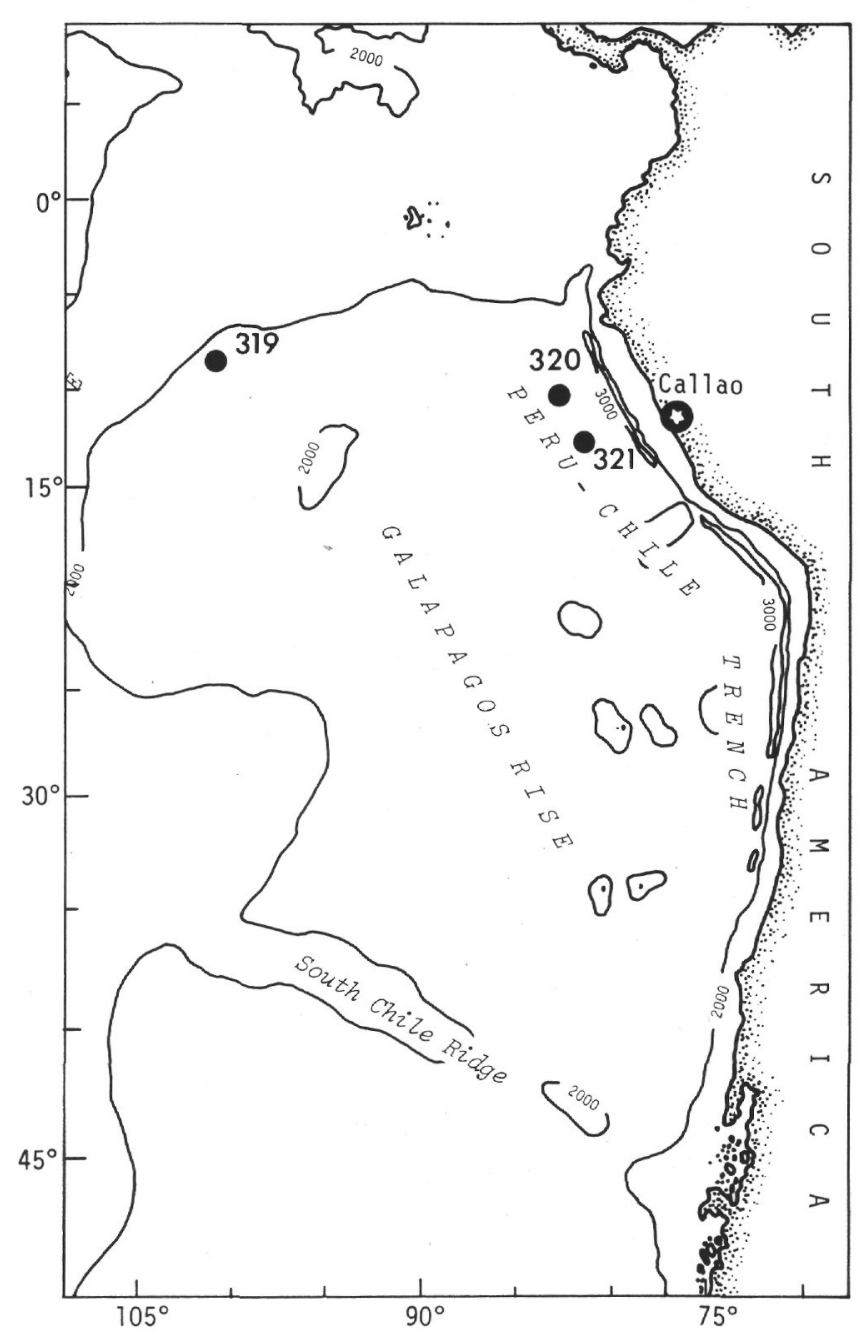

Figure 1. Location of Sites cored during Leg 34. 
shelf restricted habitat of many species. For the most part, the standard calcareous nannofossil zonation notation established by Martini (1971) has been used in this report, although in some cases zonal boundaries have been defined more in accordance with those proposed by Bukry (1973) for low latitude deep-sea sections. This system employs the use of one or more datum (highest or lowest occurrence of a taxon) to define zonal boundaries. Because of selective solution of taxa and provincialism among the calcareous nannofossils, this proves to be a more practical approach to deep-sea biostratigraphy, although it involves some sacrifice of precision. In general, Martini's zones were recognizable in the Neogene sections examined from Leg 34 and for most of the Paleogene section recovered at Site 321. Figure 2 summarizes the biostratigraphic criteria used in zonal determinations for this report.

\section{PRESERVATION}

Selective dissolution and overcalcification of calcareous nannofossils are important factors in species identification and species composition in deep-sea sediments. As previously stated, this may have a considerable effect on biostratigraphic results.

Frequently placoliths show dissolution features, with destruction of fine structures and central area enlargement, while discoasters show overcalcification. This phenomenon has been discussed in detail by Wise and Kelts (1972) and Adelseck et al. (1973). Because of this differential preservation, placolith and discoaster preservation have been recorded separately in this study. A modified preservation scale similar to that described by Bukry (1973) was used here. Briefly this scale may be described as follows:

$$
\begin{aligned}
+5= & \begin{array}{l}
\text { Complete recrystallization and secondary calcifi- } \\
\text { cation-coccoliths unrecognizable-essentially a micrite. }
\end{array} \\
+4= & \begin{array}{l}
\text { Marked recrystallization and secondary calcification-few } \\
\text { identifiable coccoliths. }
\end{array} \\
+3= & \text { Marked recrystallization and secondary calcifica- } \\
& \text { tion-some problem in identification, fine structures } \\
& \text { obscured. } \\
+2= & \text { Moderate recrystallization and secondary calcifica- } \\
& \text { tion-almost all taxa recognizable-fine structures mostly } \\
& \text { obliterated. } \\
+1= & \text { Mild recrystallization and secondary calcification-some } \\
& \text { thickening of discoasters, fine structures visible. } \\
-1= & \text { Mild etching-no difficulty in species identification-most } \\
& \text { fine structures intact. } \\
-2= & \text { Solution more marked-holococcoliths and solution-sys- } \\
& \text { ceptible taxa absent. } \\
-3= & \begin{array}{l}
\text { Marked dissolution-central areas of placoliths } \\
\text { affected-all fine. }
\end{array} \\
-4= & \begin{array}{l}
\text { Marked dissolution-only most resistant taxa remain- } \\
\text { ing-much fragmentation. }
\end{array} \\
-5= & \text { Barren of coccoliths and other calcareous material. }
\end{aligned}
$$

\begin{tabular}{|c|c|c|c|c|}
\hline \multicolumn{3}{|c|}{ ZONE } & \multicolumn{2}{|r|}{ DATUM INDICATOR } \\
\hline \multirow{3}{*}{ 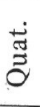 } & Emiliania huxleyi & NN21 & \multirow{2}{*}{$\frac{\mathrm{HOS}}{\mathrm{HOS}}$} & Emiliania huxleyi \\
\hline & Gephyrocapsa oceanica & NN20 & & Pseudoemiliania lacunosa, LOS Gephyrocapsa oceanica \\
\hline & $\begin{array}{l}\text { Pseudoemiliania lacunosa } \\
\text { Discoaster brouweri }\end{array}$ & $\frac{\text { NN19 }}{\text { NN18 }}$ & $\mathrm{HOS}$ & Discoaster brouweri \\
\hline \multirow{5}{*}{ 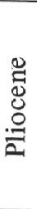 } & \begin{tabular}{|l} 
Discoaster brouwerl \\
Discoaster pentaradiatus
\end{tabular} & $\frac{1}{\text { NN17 }}$ & HOS & Discoaster pentaradiatus \\
\hline & Discoaster surculus & NN16 & HOS & Discoaster surculus \\
\hline & Reticulofenestra pseudoumbilica & NN15 & HOS & Reticulofenestra pseudoumbilica \\
\hline & Discoaster asymmetricus & NN14 & HOS & Ceratolithus tricorniculatus \\
\hline & Ceratolithus rugosus & NN13 & LOS & Discoaster asymmetricus \\
\hline \multirow{12}{*}{ 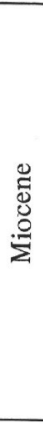 } & Ceratolithus tricorniculatus & NN12 & LOS & Ceratolithus rugosus \\
\hline & Discoaster quinqueramus & NN11 & HOS & Discoaster quinqueramus \\
\hline & Discoaster calcaris & NN10 & LOS & Discoaster quinqueramus \\
\hline & Discoaster hamatus & NN9 & HOS & Discoaster hamatus \\
\hline & Catinaster coalitus & NN8 & LOS & Discoaster hamatus \\
\hline & Discoaster kugleri & NN7 & LOS & Catinaster coalitus \\
\hline & Discoaster exilis & NN6 & LOS & Discoaster kugleri \\
\hline & Sphenolithus heteromorphus & NN5 & HOS & Sphenolithus heteromorphus \\
\hline & Helicopontosphaera ampliaperta & NN4 & HOS & Helicopontosphaera ampliaperta \\
\hline & Sphenolithus belemnos & NN3 & LOS & Sphenolithus heteromorphus, HOS Sphenolithus belemnos \\
\hline & Discoaster druggi & NN2 & $\mathrm{HO}$ & Discoaster druggi, HOS Triquetrorhabdulus carinatus \\
\hline & Triquetrorhabdulus carinatus & NN1 & LOS & Discoaster druggi \\
\hline \multirow{5}{*}{ 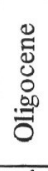 } & Sphenolithus ciperoensis & NP25 & HOS & Sphenolithus ciperoensis, HOS Reticulofenestra bisecta \\
\hline & Sphenolithus distentus & NP24 & HOS & Sphenolithus distentus \\
\hline & Sphenolithus predistentus & NP23 & LOS & Sphenolithus ciperoensis \\
\hline & Reticulofenestra umbilica & NP22 & HOS & Reticulofenestra umbilica, LOS Sphenolithus distentus \\
\hline & Helicopontosphaera reticulata & NP21 & HOS & Cyclococcolithus formosa \\
\hline \multirow[t]{2}{*}{$\dot{0}$} & Sphenolithus pseudoradians & NP20 & HOS & Discoaster barbadiensis, HOS Discoaster saipanensis \\
\hline & & & $\mathrm{LU}$ & sphenolithus pseud \\
\hline
\end{tabular}

\section{METHOD}

Light microscopy was used entirely in the examination of approximately 140 samples. Calcareous nannofossil taxa preselected for consideration are listed in Table 1. As no new species are described in this report,

Figure 2. Zones used in this study. (HOS = highest occurrence surface; LOS = lowest occurence surface). 
TABLE 1

Nannofossil Species Considered in This Report, Listed Alphabetically According to Species Name

Sphenolithus abies Deflandre in Deflandre and Fert Reticulofenestra abisecta (Muller) Roth and Thierstein Chiasmolithus altus Bukry and Percival

Helicopontosphaera ampliaperta (Bramlette and Wilcoxon) Hay Oolithus antillarium (Cohen) Reinhardt in Cohen and Reinhardt Discoaster asymmetricus Gartner

Discoaster aulakos Hay

Discoaster barbadiensis Tan Sin Hok

Sphenolithus belemnos Bramlette and Wilcoxon

Braarudosphaera bigelowi (Gan and Braarud) Deflandre

Zygrhablithus bijugatus (Deflandre) Deflandre

Discoaster binodosus Martini

Reticulofenestra bisecta (Hay, Mohler, and Wade) Roth

Discoaster bollii Martini and Bramlette

Discoaster brouweri Tan Sin Hok

Discoaster calcaris Gartner

Catinaster calyculus Martini and Bramlette

Sphenolithus capricornutus Bukry and Percival

Triquetrorhabdulus carinatus Martini

Discoaster challengeri Bramlette and Riedel

Sphenolithus ciperoensis Bramlette and Wilcoxon

Syracosphaera clathrata Roth and Hay in Hay et al.

Rhabdosphaera clavigera Murray and Blackman

Catinaster coalitus Martini and Bramlette

Quinquerhabdus colossicus Bukry and Bramlette

Helicopontosphaera compacta (Bramlette and Sullivan) Hay

Sphenolithus conicus Bukry

Ceratolithus cristatus Kamptner

Sphenolithus distentus Bramlette and Wilcoxon

Coccolithus doronicoides Black and Barnes

Discoaster druggi Bramlette and Wilcoxon

Zygolithus dubius Deflandre in Deflandre and Fert

Coccolithus eopelagicus (Bramlette and Riedel) Bramlette

\& Sullivan

Discoaster exilis Martini and Bramlette

Ericsonia fenestrata (Deflandre) Stradner

Cyclicargolithus floridanus Roth and Hay in Hay et al.

Cyclococcolithus formosa (Kamptner) Wilcoxon

Chiasmolithus grandis (Bramlette and Riedel) Gartner

Discoaster hamatus Martini and Bramlette

Sphenolithus heteromorphus Deflandre

Reticulofenestra hillae Bukry and Percival

Emiliania huxleyi Lohmann

Reticulofenestra insignata Roth and Hay in Hay et al.

Helicopontosphaera intermedia (Martini) Hay and Mohler

Markalius inversus (Deflandre) Bramlette and Martini

Discolithina japonica Takayama

Helicopontosphaera kamptneri Hay and Mohler

Cyclococcolithus kingi Roth

Discoaster kugleri Martini and Bramlette

Pseudoemiliania lacunosa (Kamptner) Gartner

Discoasterlautus Hay

Reticulofenestra laevis Roth and Hay in Hay et al.

Cyclococcolithus leptopora (Murray and Blackmann) Wilcoxon

Discoaster lidzi Hay

Cyclococcolithus macintyrei (Bukry and Bramlette) Wilcoxon

Discolithina millepuncta Gartner

Lanternithus minutus Stradner

Umbellosphaera mirabilis Lohmann

Sphenolithus moriformis (Bronnimann and Stradner)

Bramlette \& Wilcoxon

Discolithina multipora (Kamptner) Martini

Discoaster neohamatus Bukry and Bramlette

Discoaster nephados Hay

Chiasmolithus oamaruensis (Deflandre) Hay, Mohler, and Wade

Reticulofenestra oamaruensis (Deflandre) Stradner

Helicopontosphaera obliqua (Bramlette and Wilcoxon)

Roth and Thierstein

Transversopontis obliquipons (Deflandre) Hay, Mohler, and Wade Gephyrocapsa oceanica Kamptner

Sphenolithus pacificus Martini
TABLE 1 - Continued

Helicopontosphaera parallela (Bramlette and Wilcoxon) Bukry

Discoaster pentaradiatus Tan Sin Hok

Discoaster perplexus Bramlette and Riedel

Sphenolithus predistentus Bramlette and Wilcoxon

Coccolithus productus Kamptner

Sphenolithus pseudoradians Bramlette and Wilcoxon

Reticulofenestra pseudoumbilica Gartner

Discolithina pygmaea Locker

Discoaster quinqueramus Gartner

Helicopontosphaera recta (Bramlette and Wilcoxon) Muller

Isthmolithus recurvus Deflandre in Deflandre and Fert

Helicopontosphaera reticulata (Bramlette and Wilcoxon) Roth

Braarudosphaera rosa Levin and Jorger

Ceratolithus rugosa Bukry and Bramlette

Triquetrorhabdulus rugosus Bramlette and Wilcoxon

Discoaster saipanensis Bramlette and Sullivan

Discoaster saundersi Hay

Reticulofenestra scissura Hay, Mohler, and Wade

Reticulofenestra scrippsae Bukry and Percival

Discolithina segmenta Bukry and Percival

Helicopontosphaera sellii Bukry and Bramlette

Helicopontosphaera seminulum (Bramlette and Sullivan) Stradner

Bramlettius serraculoides Gartner

Coronocyclus serratus Hay, Mohler, and Wade

Ericsonia subdisticha (Roth and Hay) Roth in Baumann and Roth Discoaster surculus Martini and Bramlette

Discoaster tani Bramlette and Riedel

Rhabdosphaera tenuis Bramlette and Sullivan

Ceratolithus tricorniculatus Gartner

Sphenolithus tribulosus Roth

Discoaster trinidadensis Hay

Reticulofenestra umbilica (Levin) Martini and Ritzkowski

Discoaster variabilis Martini and Bramlette

Micrantholithus vesper Deflandre and Fert

no discussion or taxonomic description is included here. Detailed descriptions of taxa may be found by consulting Loeblich and Tappan (1966, 1968, 1969, 1970a, $1970 \mathrm{~b}$, and 1971). Data were collected using the optical scanning technique described by Blechschmidt and Worsley (in preparation). Briefly, this technique involves recording data on abundance and presence of taxa on a specially designed "mark sense" sheet similar to those used in machine graded testing. Using this technique, data are recorded by the investigator while examining a sample in a format allowing direct computer input. This technique allows rapid recording of data and direct input onto a magnetic tape for computer storage and processing.

Abundance estimates were tabulated according to a logarithmic scale and are shown in Figures 3, 4, and 5 using the more traditional letter symbols. The abundance catagories are as follows:

$\mathrm{A}=$ Abundant: $10^{1}$-ten or more specimens of a taxa per field of view at $640 \times$ magnification.

$\mathrm{C}=$ Common: $10^{\circ}-$ One to zero specimens per field of view at $640 \times$ magnification.

$\mathrm{F}=$ Few: $10^{-1}-0.1$ to 0.9 specimens per field of view at $640 \times$ magnification.

$\mathrm{R}=$ Rare: $10^{-2}-0.01$ to 0.09 specimens per field of view at $640 \times$ magnification.

$\mathrm{V}=$ Very rare: $10^{-3}-0.001$ to 0.009 specimens per field of view at $640 \times$ magnification.

Preservation data have been tabulated and are shown on the accompanying range charts as previously described. Reworking, downworking, or contamination of 


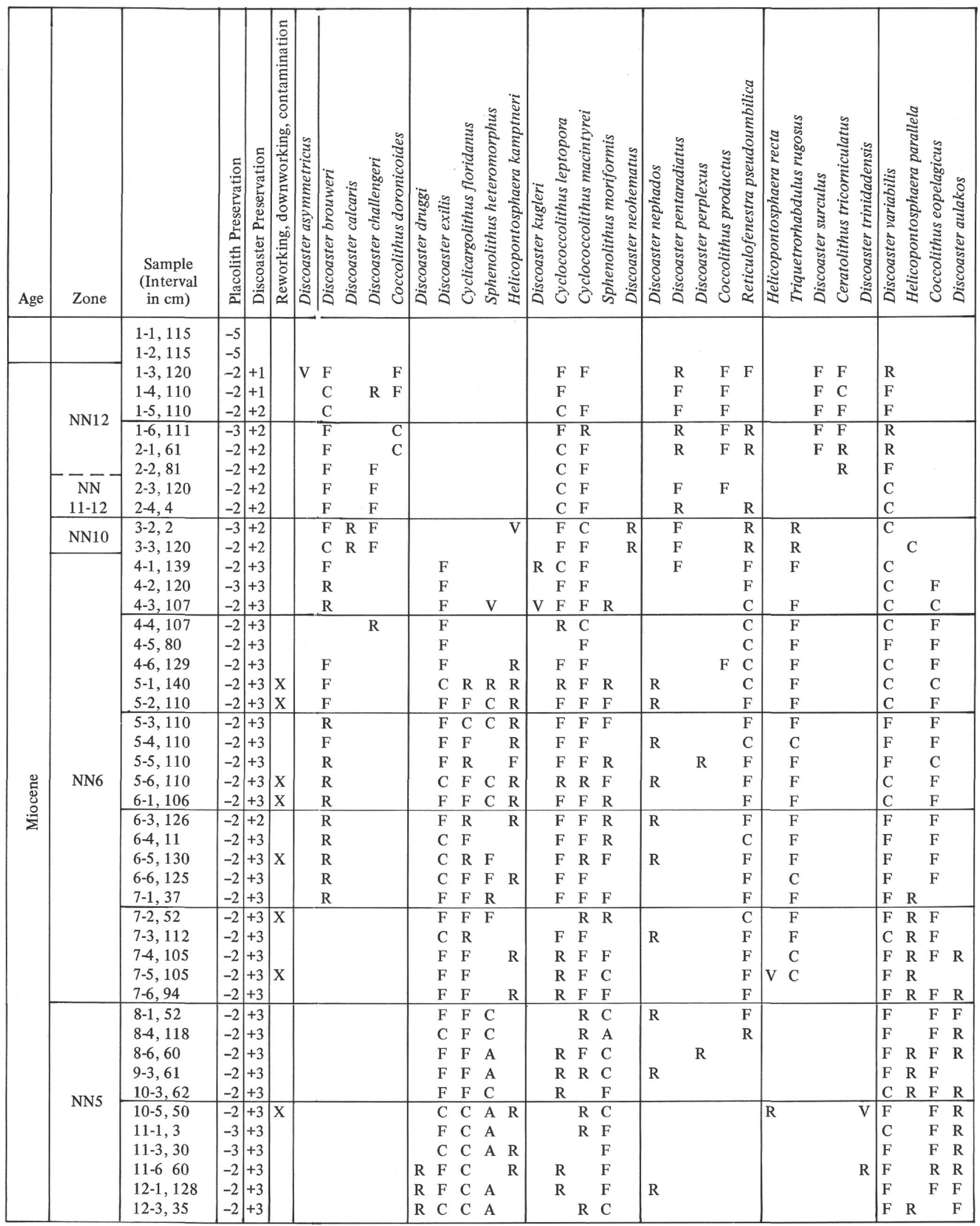

Figure 3. Distribution of calcareous nannofossils at Site 319. 


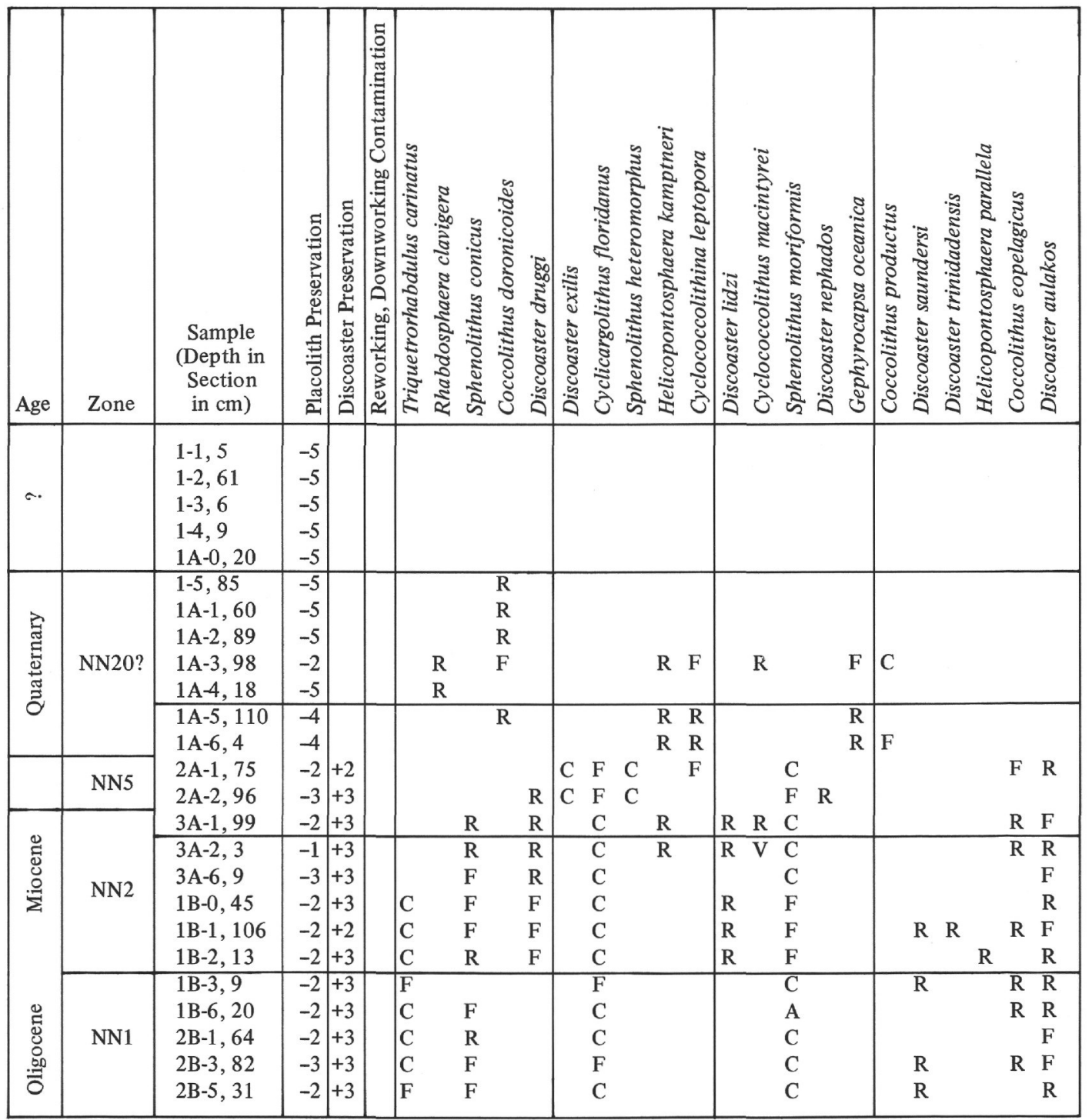

Figure 4. Distribution of calcareous nannofossils at Site 320.

a sample is denoted by an $\mathrm{X}$ in the appropriate space shown in Figures 3, 4, and 5.

\section{SITE 319-LATITUDE $13^{\circ} 01.04^{\prime} \mathrm{S}$, LONGITUDE $101^{\circ} 31.46^{\prime} \mathrm{W}$}

Site 319 was drilled in 4290 meters of water in the Bauer Deep; 116.5 meters of metalliferous nanno ooze were drilled and 84.8 meters of sediment recovered. Sediments recovered at this site range in age from Quaternary to early Miocene.

Sections 1 and 2 of Core 1 are barren of calcareous nannofossils, containing much siliceous material (primarily diatoms fragments and silicoflagellates). Section 3 of Core 1 contains a moderately well preserved upper Miocene assemblage belonging to the Ceratolithus tricorniculatus Zone dominated by Discoaster brouweri and Ceratolithus tricorniculatus. Species diversity in this section and the remainder of Core 1 is quite low. Core 2 also recovered the Ceratolithus tricorniculatus Zone. The lower part of this core (Sections 3 and 4) is also tentatively assigned to the $C$. tricorniculatus Zone, but it may also represent the Discoaster quinqueramus Zone. Overcalcification of discoasters makes differentiation difficult. C. tricorniculatus is not found in Sections 3 and 4. Discoaster brouweri, Discoaster variabilis, and Cyclococcolithus leptoporus dominate the assemblage. A portion of Core 3 was lost in coring. An assemblage belongs to the Discoaster calcaris Zone with common Triquetrorhabdulus rugosus, $D$. brouweri, $D$. variabilis, $C$. leptoporus, and Cyclococcolithus macintyrei. Discoaster calcaris was found in Section 3. Tentative age assignment of Core 4 placed it in the Discoaster exilis Zone. Discoaster kugleri appears very sparsely in Section 1 of this core. Triquetrorhabdulus rugosus, D. exilis, $D$. variabilis, and C. leptoporus are common in this core. Helicopontosphaera kamptneri also appears rarely throughout this core. Some reworking was apparent in Core 5 with a dominant assemblage characteristic of the D. exilis Zone. Reworked Sphenolithus heteromorphus was detected in Sections 1, 2, and 5. This reworking was also apparent in Core 6 and to some extent in Core 7, both of which contain a dominant floral assemblage 


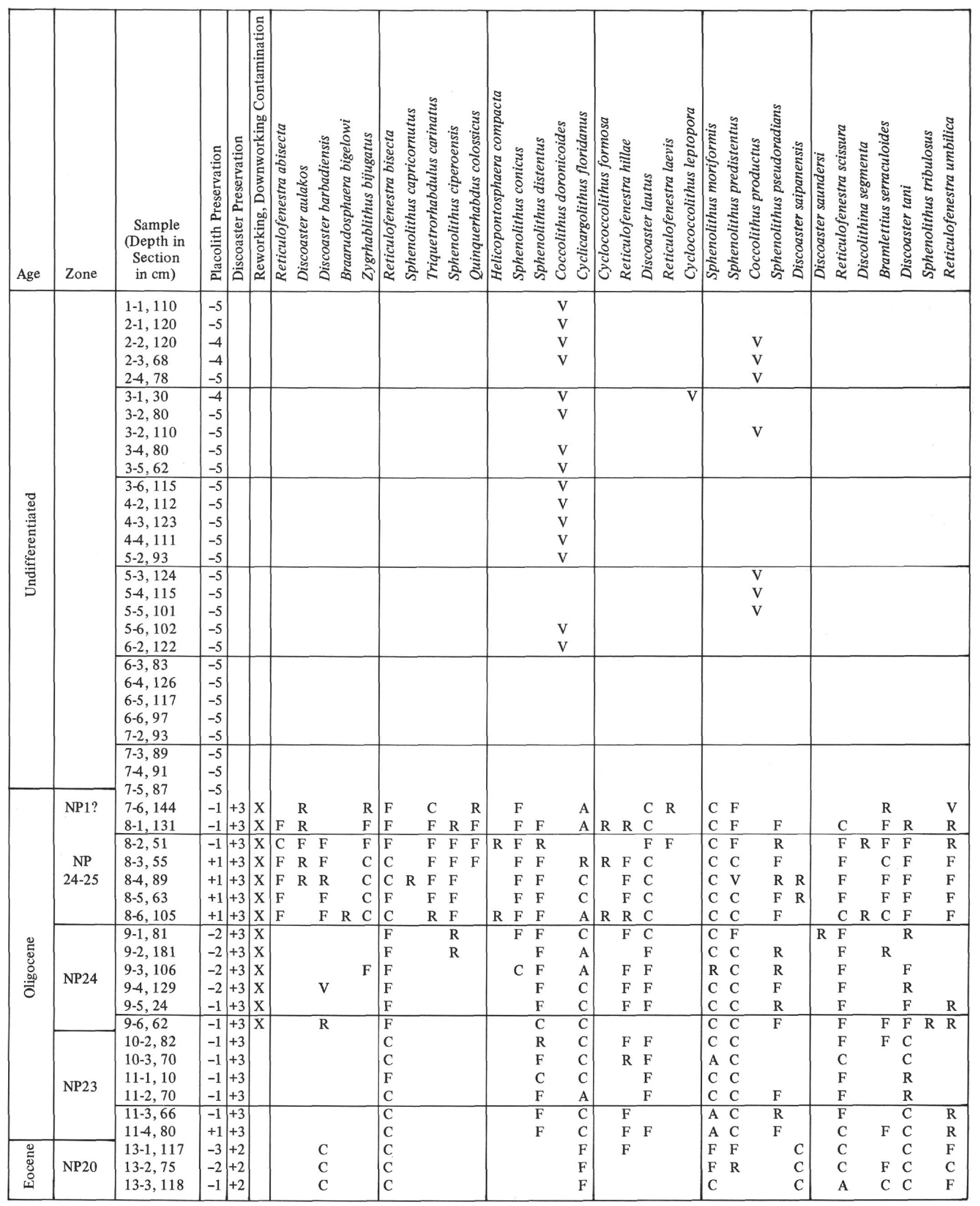

Figure 5. Distribution of calcareous nannofossils at Site 321. 
characteristic of the $D$. exilis Zone. Common species present are $T$. rugosus, D. variabilis, D. exilis, C. leptoporus, and C. macintyrei. Cores $8,9,10,11$, and 12 all recovered nanno ooze with a flora characteristic of the Sphenolithus heteromorphus Zone. S. heteromorphus, $C$. macintyrei, Discoaster aulakos, and $D$. variabilis are common in this assemblage. D. exilis disappears in Core 12, in which discoasters of the Discoaster deflandre group become more dominant.

Preservation: Calcareous nannofossils in all sections show some effects of dissolution. This is particularly marked in the upper Miocene sediments recovered at this site. The less solution-resistant genera such as Discolithus and Braarudosphaera are not preserved at all. Discoasters showed marked overcalcification in almost all samples examined, making identification quite difficult in many cases. This factor is much more prominent in the lower Miocene sediments recovered. Preservation of placoliths is generally fairly good with general destruction of fine structures. For the most part, this did not hamper identification.

\section{SITE 320-LATITUDE $9^{\circ} 00.40^{\prime} \mathrm{S}$, LONGITUDE $83^{\circ} 31.80^{\prime} \mathrm{W}$}

At Site 320, located approximately 200 miles from the west coast of South America, 155 meters of sediment were cored. Four holes were drilled in which 84.5 meters of sediment were recovered ranging in age from Quaternary to early Miocene. The Quaternary interval at this site is a siliceous clay. Lower Miocene sediments are a nanno-foram ooze.

Three cores were recovered at Hole 320. Sections 1 and 2 of Core 1 are barren of calcareous nannofossils. Section 3 contains a fairly well preserved Pleistocene assemblage belonging to the Gephyrocapsa oceanica Zone. This assemblage includes $C$. leptoporus, $G$. oceanica, $H$. kamptneri, Rhabdosphaera clavigera, and Coccolithus doronicoides. Section 4 is barren of calcareous nannofossils and Sections 5 and 6 contain an assemblage similar to that found in Section 3. Preservation in these two sections is poor with only more resistant taxa remaining. Core 2 recovered lower Miocene sediments at a subbottom depth of 73.5 meters. The nannofossil assemblage in this core is representative of the $S$. heteromorphus and common $C$. leptoporus and $C$. floridanus. Core 3 recovered sediment from 103.5 to 111.5 meters. The nanno-foram ooze of this core contains a floral assemblage representative of the Discoaster druggi Zone. Reticulofenestra abisecta, Sphenolithus moriformis, $D$. druggi, and $D$. aulakos are among the taxa found in samples from this core.

Hole 320A: All samples from the only core recovered are barren of calcareous nannofossils.

Hole 320B: Two cores were recovered at a depth below mudline of 136.0 to 155.0 meters. Both penetrated lower Miocene sediments. Sections 1 and 2 of Core 1 contain nannofossils characteristic of the $D$. druggi Zone with common Cyclicargolithus floridanus, S. moriformis, Triquetrorhabdulus carinatus, and $D$. druggi. Sections 3 through 6 are assigned to the $T$. carinatus Zone including $T$. carinatus, Reticulofenestra scrippsae, $\boldsymbol{S}$. moriformis, and C. floridanus. Core 2 contains a similar assemblage and is also assigned to the $T$. carinatus Zone.

Preservation: Nannofossils recovered at Site 320 are generally poorly preserved in the Pleistocene interval. The successive appearance and disappearance of calcareous nannofossils in Core 1 of Hole 320 may represent Pleistocene fluctuations in the CCD. Nannofossils in the lower Miocene interval of the cores collected are relatively well preserved. Discoasters are frequently badly overcalcified making identification impossible. Fine structures of placoliths were destroyed, but identification of taxa was not impaired.

\section{SITE 321-LATITUDE $1^{\circ}{ }^{\circ} 1.29^{\prime}$, LONGITUDE $81^{\circ} 54.24^{\prime}$}

Site 321 was drilled in 4827 meters of water on the eastern edge of the Nazca plate about 200 miles west of the coast of Peru. Of the 125 meters of sediment drilled at this site, 81.3 meters were recovered. The lower 67 meters contain calcareous nannofossils ranging in age from early Miocene/late Oligocene to late Eocene.

Cores 1 through 6, recovered at Site 321, are barren of calcareous nannofossils. Sections 1 through 5 of Core 7 are also barren of nannofossils. Section 6 of Core 7 shows the sudden appearance of a fairly well preserved and diverse nannoflora assemblage probably belonging to the Triquetrorhabdulus carinatus Zone. Reworking is prominent in this section with lower Oligocene and Eocene taxa forming a minor component of most of the assemblages observed. This reworking makes it necessary to base zonal definitions on lowest occurrences when possible. Core 8 has been assigned to the Sphenolithus distentus/Sphenolithus ciperoensis zones with common $T$. carinatus, $S$. ciperoensis, $R$. abisecta, $C$. floridanus, Reticulofenestra bisecta, and Reticulofenestra scissura. Considerable reworking is apparent in all sections of this core. Surprisingly a few specimens of Braarudosphaera bigelowi are present in Section 6 of Core 8 . Core 9 contains an assemblage similar to that seen in Core 8, characteristic of the $S$. distentus Zone. Reworking is also pronounced in this core. S. ciperoensis, $S$. distentus, $R$. bisecta, and $C$. floridanus are among the more common taxa recognized in this core. Core 10 recovered a nannofossil assemblage characteristic of the Sphenolithus predistentus Zone with $S$. predistentus, $S$. distentus, $R$. bisecta, Reticulofenestra hillae, $C$. floridanus, and Discoaster tani among the taxa found at this level. The nannofossil assemblage found in Core 11 is similar to that found in Core 10 . Some reworking is apparent, but it is less pronounced than in the upper cores. Core 13 contains an upper Eocene assemblage including Discoaster barbadiensis, Discoaster saipanensis, Bramlettius serraculoides, Cyclococcolithus formosus, and Reticulofenestra umbilica. This core has been assigned to the Sphenolithus pseudoradians Zone.

Preservation: Complete dissolution of calcite is seen in the upper cores at Site 321. Preservation of the calcareous nannofossils in the Oligocene-Eocene sediments recovered is generally good with destruction of most of the fine structure in placoliths and a general lack of solution-susceptible taxa. An exception to this is the appearance of Braarudosphaera bigelowi in Core 8 . Dissolution is more marked in the Eocene sediments of Core 13. 


\section{ACKNOWLEDGMENTS}

I would like to express my thanks to Dr. T.R. Worsley for helpful suggestions and critical review of this paper and to $\mathrm{Mr}$. Craig Suchland for computer processing of data presented here. This is contribution 871 from the University of Washington. This research was partially funded by NSF Grant No. GA36628X1.

\section{REFERENCES}

Adelseck, C.G., Jr., Geehan, G.W., and Roth, P.H., 1973. Experimental evidence for the selective dissolution and overgrowth of calcareous nannofossils during diagenesis: Geol. Soc. Am. Bull., v. 84, p. 2755.

Blechschmidt, G. and Worsley, T.R., in preparation. The application of optical scanning (machine recognition of characters) to computerized paleontologic data.

Bramlette, M.N. and Sullivan, F.R., 1961. Coccolithophorids and related nannoplankton of the early Tertiary in California: Micropaleontology, v. 7, p. 129.

Bramlette, M.N. and Wilcoxon, J.A. 1967. Middle Tertiary calcareous nannoplankton of the Cipero section, Trinidad, W.I.: Tulane Stud. Geol., v. 5, p. 93.

Bukry, D., 1973. Coccolith stratigraphy, eastern equatorial Pacific, Leg 16, Deep Sea Drilling Project. In van Andel, T.H., Heath, G.R., et al., Initial Reports of the Deep Sea Drilling Project, Volume 16: Washington (U.S. Government Printing Office), p. 653.

Edwards, A., 1971. A calcareous nannoplankton zonation of the New Zealand Paleogene. In Farinacci, A. (Ed.), Plankt. Conf. Second, Rome 1970 Roma (Tecnoscienza), p. 381 .
Gartner, S., Jr., 1969. Correlation of Neogene planktonic foraminifer and calcareous nannofossil zones: Trans. Gulf Coast Assoc. Geol. Soc., v. 19, p. 585.

Hay, W.W., Mohler, H.P., Roth, P.H., Schmidt, R.R., and Boudreaux, J.E., 1967. Calcareous nannoplankton zonation of the Cenozoic of the Gulf Coast and CaribbeanAntillean area, and transoceanic correlation: Trans. Gulf Coast Assoc. Geol. Soc., v. 17, p. 428.

Loeblich, A.R. and Tappan, H., 1966. Annotated index and bibliography of the calcareous nannoplankton: Phycologia, v. 5 , p. 81 . 1968. Annotated index and bibliography of the calcareous nannoplankton II: J. Paleontol. v. 42, p. 584. , 1969. Annotated index and bibliography of the calcareous nannoplankton III: J. Paleontol., v. 43, p. 568. , 1970a. Annotated index and bibliography of the calcareous nannoplankton IV: J. Paleontol., v. 44, p. 558. 1970b. Annotated index of the calcareous nannoplankton V: Phycologia, v. 9, p. 157. 1971. Annotated index and bibliography of the calcareous nannoplankton VI: Phycologia, v. 10, p. 315. , in preparation. Annotated index and bibliography of the calcareous nannoplankton VII.

Martini, E., 1971. Standard Tertiary and Quarternary calcareous nannoplankton zonation. In Farinacci, A. (Ed.), Plankt. Conf. Second, Rome 1970 Proc. Roma (Tecnoscienza), p. 739.

Roth, P.H., 1970. Oligocene calcareous nannoplankton biostratigraphy: Eclog. Geol. Helv., v. 63, p. 799.

van Andel, T.H., Heath, G.R., and Moore, T.C., Jr., in preparation. Cenozoic tectonics, sedimentation and paleooceanography of the central equatorial Pacific.

Wise, S..W. and Kelts, K..R., 1972. Inferred diagenetic history of a weakly silicified deep sea chalk: Gulf Coast Assoc. Geol. Soc. Tran., v. 22, p. 177. 